\title{
PRO-POOR VALUE CHAINS FOR SMALL SCALE FARMING INNOVATION: SUSTAINABILITY IMPROVEMENTS THROUGH ICT
}

\author{
B. Matsenjwa ${ }^{1}$, S.S. Grobbelaar ${ }^{1,2 *} \&$ I.A. Meyer ${ }^{3}$
}

\section{ARTICLE INFO}

\section{Article details}

Submitted by authors 7 May 2019

Accepted for publication 13 Nov 2019

Available online $\quad 12$ Dec 2019

\section{Contact details}

* Corresponding author ssgrobbelaar@sun.ac.za

Author affiliations

1 Department of Engineering and Technology Management, Graduate School of Technology Management, University of Pretoria, South Africa

2 DST-NRF CoE in Scientometrics and Science, Technology and Innovation Policy, Stellenbosch University, South Africa

3 Department of Industrial Engineering, Stellenbosch University, South Africa

DOI

http://dx.doi.org/10.7166/30-4-2176
ABSTRACT

The success of small-scale farmers in pro-poor value chains is constrained by aspects related to government policies, research and training, community issues, and the quality of existing information and communication technology (ICT) tools. This article discusses effective strategies to increase the access to and adoption of ICT by small-scale farmers. Based on a literature review and an expert opinion survey, it identifies and assesses the key factors that facilitate increased ICT access and adoption. Investment in the development of ICT for rural small-scale farmer development is needed, to customise farming ICT to be user-friendly, and to conduct research on the use of simpler but more appropriate technologies to facilitate ICT adoption and use for value chain development.

\section{OPSOMMING}

Die sukses van kleinboere in armoedeverligting-gerigte waarde-kettings word beperk deur, o.a., regeringsbeleid, navorsing en opleiding, gemeenskap uitdagings, en die gehalte van bestaande inligting- en kommunikasiehulpmiddels. Effektiewe strategieë om toegang tot, en die gebruik van, inligting- en kommunikasie-hulpmiddels deur kleinboere te bevorder is bespreek. 'n Literatuurstudie en kenner meningspeiling is gebruik om die kernfaktore wat toegang en gebruik bevorder te identifiseer en evalueer. Investering in die ontwikkeling van inligting- en kommunikasiehulpmiddels vir kleinboerontwikkeling is nodig om dit gebruikersvriendelik te maak. Navorsing oor eenvoudiger, toepasliker tegnologie om die aanvaarding en gebruik van hierdie hulpmiddels in waardekettingontwikkeling te bevorder is ook nodig.

\section{SIFINYETO}

Imphumelelo yebalimi labasaphakama labasetindzaweni letiphuyile ivinjwa tintfo letimayelana netinchubomgomo tahulumende, luphenyo ngebalimi, kuceceshwa kwabo, tinkinga temiphakatsi labakuyo, lizinga lebuhle nome lebunjalo betinsita nome bemathulusi lakhona ethekhnoloji yetekuchumana (ICT). Le-athikili ikhuluma ngemasu latawuletsa kutfutfuka kwelizinga lekutfolakala nekwemukelwa kweICT kubalimi labasaphakama. Ngekubuka lucwaningo leselwentiwe kanye nembono welucwaningo lolwentiwe bochwepheshe, le-athikili itfola iphindze ihlolisise timphawu letimcoka-letitawenta kutsi kutfutfukiswe kutfolakala nekwemukelwa kwe-ICT. Kuyadzingeka kutsi kutjalwe timali ekutfutfukiseni i-ICT kute kutowutfutfukiswa balimi labasaphakama labasemakhaya, nekwetayeta kutsi Iwati Iwetekulima kanye ne-ICT kukhone kusebentiseka kuphindze kwentiwe luphenyo mayelana nekusetjentiswa kwethekhnoloji lemelula kepha lefanelekile kute kutowenta kutsi kwemukelwe kuphindze kusetjentiswe i-ICT ekuletseni intfutfuko kulokutidzingo letiphelele temkhicito kusuka kumlimi uyofika lapho utsengiswa kubasebentisi bawo khona. 
South African small-scale farmers in pro-poor value chains have failed, due to limitations related to government policies, research and training, community issues, and existing information and communication technology (ICT) tools. In particular, the limited access of small-scale farmers to agricultural technologies is considered to contribute to low production efficiency. ICTs have long been seen as enablers of development, with a potentially significant impact [1]. In agriculture, ICTs have the potential to transform and develop innovation, entrepreneurship, and economic growth and development [2], and to enhance the efficiency and productive output of emerging farmers. There is a need to explore these areas to improve the success of pro-poor value chains, with the aim of increased food production and job creation, and reduced poverty in rural areas.

The ability of small-scale farmers to access mainstream markets is limited, due, among other things, to the domination of formal national fresh produce market channels and the need to compete with well-established supermarkets [3, 4]. Value chains have been considered as a mechanism that could facilitate market access, thus enabling an increase in small-scale farmers' income [5]. A value chain constitutes a complete range of functions or activities, as well the relevant market actors that are required to bring a product from design and development to operation and beyond [6]. In smallscale farmer development, the main goal of value chain development is the improvement of the farmer market system for the benefit of all key market actors, to provide income and create employment. Market-based solutions are suggested to provide a long-lasting and sustainable impact that will not distort local markets [7].

Technology and innovation are essential for the development of pro-poor value chains, but are dependent on the rate of absorption and assimilation of international and domestic technology transfer to the local market. Small-scale farmers are receivers of new technologies and knowledge, and the lack of uptake could be the result of low adaptation flexibility and poor proactivity [8]. The major constraints to ICT uptake in pro-poor value chains include the high cost of technology, poor understanding of the value of ICTs, lack of awareness, and personal impediments (e.g., the lack of ICT skills or literacy). These constraints can be alleviated by involving the community in efforts to adopt new technologies. This requires the effective participation of communities to empower their leaders to effectuate ICT tools, identify optimal solutions, and ensure relevant local content [9].

Research has shown that rural communities lack basic training in agricultural ICTs, and that there has not yet been adequate time and resource investment to ensure effective adoption. The provision of training and support services can facilitate the increased adoption of ICTs and develop information literacy among stakeholders. There is a need to customise existing ICTs to be user-friendly, and research and development (R\&D) can enable the development of simple farming ICT tools for use by the average rural small-scale farmer [10]. It is also necessary for government to prioritise agriculture and rural viability to address explosive rural migration, facilitate food security, ensure food quality, and urgently minimise environmental abuse. A positive impact requires behavioural change, where behaviour is determined by incentives and capacities that are influenced by governance structures [11]. Government could therefore establish policies to reduce the digital divide by supporting legislation that controls competition, opens telecommunication markets, and develops rural ICT infrastructure [12].

This study develops a thorough understanding of the many challenges to the provisioning of adequate ICT access and adoption by rural small-scale farmers, with a focus on government policies, research and training, community issues, and existing ICT tools. It seeks to identify simple approaches that can be used to increase ICT access and adoption rates, with the ultimate aim of developing smallscale farming in South Africa's rural areas.

To this end, the study aims to:

- $\quad$ analyse the factors that impede ICT access and adoption;

- identify strategies to facilitate increased ICT access and adoption for the development of propoor rural value chains; and

- $\quad$ identify practical approaches to be implemented for increased ICT access and adoption in rural areas. 
The remainder of the document is structured as follows. First, the research method is described (Section 2), after which the results of a literature review to identify the key challenges of emerging farmers are discussed (Section 3). These challenges are integrated into a conceptual model (Section 4), which is then used to examine the perspectives of farmers and agricultural experts on ICT adoption in small-scale rural farming (Section 5). The conclusions and recommendations are presented in Section 6.

\section{RESEARCH METHOD}

The research addresses the following questions:

- What are the challenges to access to, and uptake of, ICTs by small-scale farmers in pro-poor value chains?

- Which key aspects should be considered in addressing these challenges?

- What resources are needed to strengthen the capacity of innovation systems to effectively develop, adopt, and diffuse new technologies for small-scale farmers?

- Which simple tools can farmers implement and adopt for the development of pro-poor value chains?

To answer these questions, the research combined a literature review with a primary data collection process aimed at gathering expert opinion on the aspects that were identified from the literature. The information was then integrated to identify strategies to improve the capacity of ICT innovation systems to effectively develop, adopt, and diffuse new technologies for small-scale farmers, with the aim of improving food security and reducing poverty in rural areas.

\subsection{Literature review and concept model development}

A systematic literature review was undertaken to identify the challenges that affect the adoption and use of ICTs in rural small-scale value chains. The approach to the analysis of the identified literature is summarised in Table 1.

Table 1: Literature review approach

\begin{tabular}{|c|c|c|}
\hline Step & Summarised goal of step & Description of step \\
\hline $\begin{array}{l}\text { Research } \\
\text { questions and } \\
\text { goals }\end{array}$ & $\begin{array}{l}\text { Determine the root causes of the } \\
\text { poor access to and adoption of ICT. } \\
\text { This will help to develop } \\
\text { improvement strategies }\end{array}$ & $\begin{array}{l}\text { - Analyse key challenges faced by small-scale } \\
\text { farmers in pro-poor value chains } \\
\text { - Analyse the effectiveness of existing ICT } \\
\text { tools }\end{array}$ \\
\hline Focus & $\begin{array}{l}\text { Government policies, training and } \\
\text { research, community issues, } \\
\text { existing ICT tools }\end{array}$ & $\begin{array}{l}\text { - Compare ICT access and adoption rates per } \\
\text { programme, and identify areas for } \\
\text { improvement }\end{array}$ \\
\hline $\begin{array}{l}\text { Selection of cases } \\
\text { and theories }\end{array}$ & $\begin{array}{l}\text { Reasoning behind selection of } \\
\text { theories used }\end{array}$ & $\begin{array}{l}\text { - Compare arguments and basis of theories } \\
\text { - Compare arguments and basis of cases }\end{array}$ \\
\hline Data generation & $\begin{array}{l}\text { Draw inferences from the cases } \\
\text { investigated }\end{array}$ & $\begin{array}{l}\text { Impact hypotheses: } \\
\text { - What effective methods are used to } \\
\text { increase ICT access? } \\
\text { - How do these assist in operationalising the } \\
\text { listing of observations that can deny or } \\
\text { confirm expected mechanisms to drive } \\
\text { outcomes? } \\
\text { Descriptive inference: } \\
\text { - How do selected methods allow for } \\
\text { development of practical actions and } \\
\text { strategies? }\end{array}$ \\
\hline Data analysis & $\begin{array}{l}\text { Highlight differences within the } \\
\text { theories concerning the level of } \\
\text { congruence between observations } \\
\text { and expectations }\end{array}$ & $\begin{array}{l}\text { - Compare the effectiveness of methods } \\
\text { against actual observations and } \\
\text { expectations } \\
\text { - Conduct an in-depth analysis of the pros } \\
\text { and cons, and how programme strategies } \\
\text { can complement each other to create a } \\
\text { more comprehensive framework }\end{array}$ \\
\hline Generalisation & $\begin{array}{l}\text { Draw conclusions beyond the cases } \\
\text { investigated }\end{array}$ & $\begin{array}{l}\text { - Compare the proposed strategies in terms } \\
\text { of an explanatory typology of usefulness } \\
\text { - } \quad \text { Determine what works and what does not }\end{array}$ \\
\hline
\end{tabular}


Following the analysis of the literature, a conceptual model of ICT adoption and use in rural emerging farmer value chains was developed.

\subsection{Survey of expert opinion}

Following the conceptualisation based on the secondary data, the research questions were further examined by collecting primary data through a questionnaire survey of expert opinions.

The target population for the study was 80 South African domestic and professional farmers, experts in the agriculture industries, and academics. The latter included PhD students and lecturers from universities in Gauteng, the Western Cape, the Eastern Cape, and KwaZulu-Natal provinces who were conducting research in engineering, agriculture, and science. Industry workers included economists, consultants, professional farmers, engineers, extension officers, and farmer programme managers. A stratified random sampling technique was used, since it has the advantage that every element in the defined population has a known, independent, and equal chance of being selected as a subject, and the selection of one element does not affect the selection of another element. A random sample of 50 respondents was taken, representing 62.25 per cent of the total targeted population. From the 50 distributed questionnaires, 23 were answered - a response rate of 46 per cent.

Respondents received ample time to complete the questionnaires, and assistance was given where required. The questionnaire comprised two main parts. The first part was concerned with generating an understanding of the challenges faced by small-scale farmers, based on the challenges identified in the literature review. Respondents were asked to prioritise these challenges to determine the most important areas to address first. The questionnaire consisted of the five variable items, which were assessed using a five-point scale. The second part of the questionnaire was concerned with determining effective strategies to address the challenges. The questionnaire was first pre-tested to ensure the questions' clarity, and to measure whether it could be completed within a reasonable period of time. The questionnaire was then modified, based on the suggestions and comments made by the pre-test subjects. Re-wording of the questionnaire was done to eliminate any jargon, leading questions, or inconsistencies.

\section{LITERATURE REVIEW}

\subsection{ICTs and value chains as enablers of small-scale farmer development}

Rural small-scale farmers in South Africa face several challenges, including poverty, changes in rural and agricultural policies, climate variability, disease outbreaks, and land degradation [13]. This leads farmers to migrate to urban areas in search of resources that are not available in rural areas. Farmers also lack important information on how to mitigate the challenges that they face [14]. Rural small-scale farmers have limited access to agricultural technologies. This results in a technology divide between rural and urban areas, decreased competitiveness, increased unemployment, decreased yields, and susceptibility to pests and diseases. Many of these challenges could be attributed to limited access to ICT tools that would facilitate information sharing among farmers [15].

Pro-poor value chains involve a complete range of functions or activities, together with the relevant market actors that are required to bring products from production to consumption. Limited skills and a lack of access to infrastructure and finance pose barriers to the participation of small-scale farmers in agricultural markets, thus limiting their success [16].

Although value chains have been considered as devices that could enable an increase in small-scale farmers' income by linking them to large markets, this approach does not come without challenges. Small-scale farmers' participation in commercial value chains is hindered by the inability to produce high quality products consistently, and in sufficient volumes that can be traced throughout the value chain [17]. Logistics constraints associated with remote rural locations further hamper market access and distribution. These include distance to markets; poor infrastructure; low demand for, and low availability of, logistics services; and high logistics costs [6]. Value chain-related constraints include a lack of coordination, limited cooperation, the subsequent exclusion of smaller players, and channel dominance by large commercial entities. 
Realising the full benefit of value chain development requires the initiatives of the private sector to be complemented with targeted investment in producer and community assets. Researchers have identified the following strategies for improving pro-poor value chains: imitating leading firms by adapting their product proposition and buying practices; investing in the capability to meet processing and production requirements; investing in diverse sustainable livelihood strategies; and adapting supply chain structures and trading relationships for smallholder sourcing [18]. Farmers' cooperatives or associations and poorer small-scale producers can form joint ventures and invest in capturing market opportunities. Farmers might also need to restructure the value chain, develop their adherence to standards, improve governance, and obtain certification to increase value chain performance. Farmers can also co-invest to reduce the financial load when their cash flow is limited [19]. Small-scale farmers can benefit greatly by adapting the trading models of intermediaries and lead firms for smallholder sourcing. Supply chain coordination, which refers to the relationships between actors at nodes, has shown durable trade benefits for farm producers. Producers strengthen their supply and negotiation capabilities in order to increase their human ability and capital, to coordinate a response to market signals. Effective intermediaries are required to link small-scale producers to formal markets; they are also essential hubs for services, and for assisting farmers to satisfy market needs. Intermediary structures can include private processing companies, independent trade networks, producer cooperatives, and lead farmers [20].

\subsection{Linking ICTs with farming value chains, research, and training}

The literature provides evidence of the role of research and training in emerging farmer value chain development through ICTs. First, research into new ways of providing support for farmers is paramount for increased value chain productivity. With the increasing complexity of ICTs, authors have identified sufficient training programmes to help farmers exploit technologies that could enable higher levels of efficiency in farm enterprise [15]. Targeted technical capacity development and training for specialised activities along the value chain are also essential for the development of value chains. Research has focused on designing specific instruments to enable practical progress, and on delivering specific services to different value chain actors and to society [21]. Research enables the development of simpler ICT tools to increase ICT access, and to trigger learning that leads to the adoption of more advanced ICTs [22]. Effective training plans are required to expose farmers to efficient research, to develop effective pro-poor value chains.

\subsection{Linking ICTs with farming value chains and government policies}

The adoption of ICTs in value chains is hindered by a lack of understanding and awareness of the needs and challenges of small-scale farmers in rural areas. There is a need to reflect accurately the needs of farmers by involving rural stakeholders in meaningful dialogue with regulators and government officials, so that policy makers accurately reflect the needs of farmers. The government can invest in high quality value chain (VC) research that will use primary data to identify the root causes of the poor performance of pro-poor value chains. Equally, investment in high quality agriculture VC research is required to identify the root causes of the poor performance of value chains [23]. VC analysis can contribute to the development of solutions by allowing policy makers to [24]:

- uncover the dynamics of economic flow, and the coercive and organisational activities between producers, suppliers, and different sectors;

- understand the position of new entrants into existing markets, and identify the gatekeepers in the value chain;

- $\quad$ understand the market interactions and upgrading; and

- uncover the flow of the distribution of rents and incomes, and how these rewards change over time.

The benefits of incorporating ICT platforms with government policies are [25]:

- $\quad$ providing small-scale farmers with affordable, scalable, appropriate, sensible, and participatory ICTs;

- developing physical ICTs and human resource infrastructure in rural areas that can help farmers gain access to time-sensitive information;

- linking small producers, traders, processors, and others in the value chain to facilitate effective communication, partnership establishment, and information exchange;

- $\quad$ establishing stronger scientific and technological institutions; 
- $\quad$ expanding the ICT field applications from agriculture to agro-industry;

- developing programmes for training small-scale farmers on ICTs, as well as public-private partnerships that will assist to alleviate funding and resource scarcities for investments in physical and human capital;

- developing government regulations that enhance the benefits of ICTs for business and the public; and

- ensuring end-user involvement in planning future ICT developments and uptake.

\subsection{Linking ICTs with farming value chain and community issues}

The use of ICTs to address community issues in rural areas could facilitate an increase in ICT adoption in these areas. ICTs can be used to address the following community issues [26]:

- consistent provision of sufficient electricity supply, water supply, and education, and affordable farming technology and health care;

- improved rural economic conditions by improving the local businesses and enabling development of new business ventures - this will also result in increased employment opportunities;

- development of human capital by providing incremental technical learning;

- improved human skills by providing access to valuable information and ICT tools that help farmers to minimise soil erosion and provide the best grazing systems;

- improved access to financial services and small community grants; and

- improved rural livelihoods and food production through the use of innovative technology.

\subsection{Linking ICT with farming value chain and existing tools}

The adoption of complex ICTs is proving to be a slow process that takes a long time. The adoption rate can be improved by blending new ICT tools with existing ICT tools that are already used by small-scale farmers. The use of simpler technologies may produce better results, take projects forward, and trigger learning that leads to the increased adoption of more advanced ICTs [27]. Too much innovation can be a hindrance by blocking the use of older technologies that are potentially more effective and affordable [28]. Focusing on improving existing and available ICTs used by small scale farmers can also minimise the cost of the diffusion of new ICTs. This will avoid investment in and oversupply of superfluous information and of the latest, rather than the most relevant, ICTs. In addition, this will ensure ICT benefit sustainability by incorporating proven ICTs in innovative adoption programmes for agricultural production and the facilitation of rural viability [29].

\section{PROPOSED MODEL OR CONCEPTUAL METHOD}

The conceptual model in Figure 1 outlines the aspects that were investigated by the literature review. The model categorises the challenges of ICT access and adoption into factors related to (1) government policies, (2) training and research, (3) existing innovations, and (4) the state of the community [30], and outlines their relationship to efficient pro-poor value chains. It is postulated that collaborative improvements in these different sectors can facilitate an effective ICT programme, which will increase the access to and adoption of effective ICT tools and so enhance the efficiency of pro-poor value chains. The conceptual model guides the research towards achieving the objectives that were outlined in the introduction.

The conceptual model shows the relationship that exists between the challenges of ICT access and adoption related to government policies, training and research, and existing innovation.

Poor access to ICTs in rural areas presents opportunities for exploring new forms of collaborative problem-solving, new ways of learning, and new development paths that promote the rapid adoption of ICTs by small-scale farmers in pro-poor value chains. 


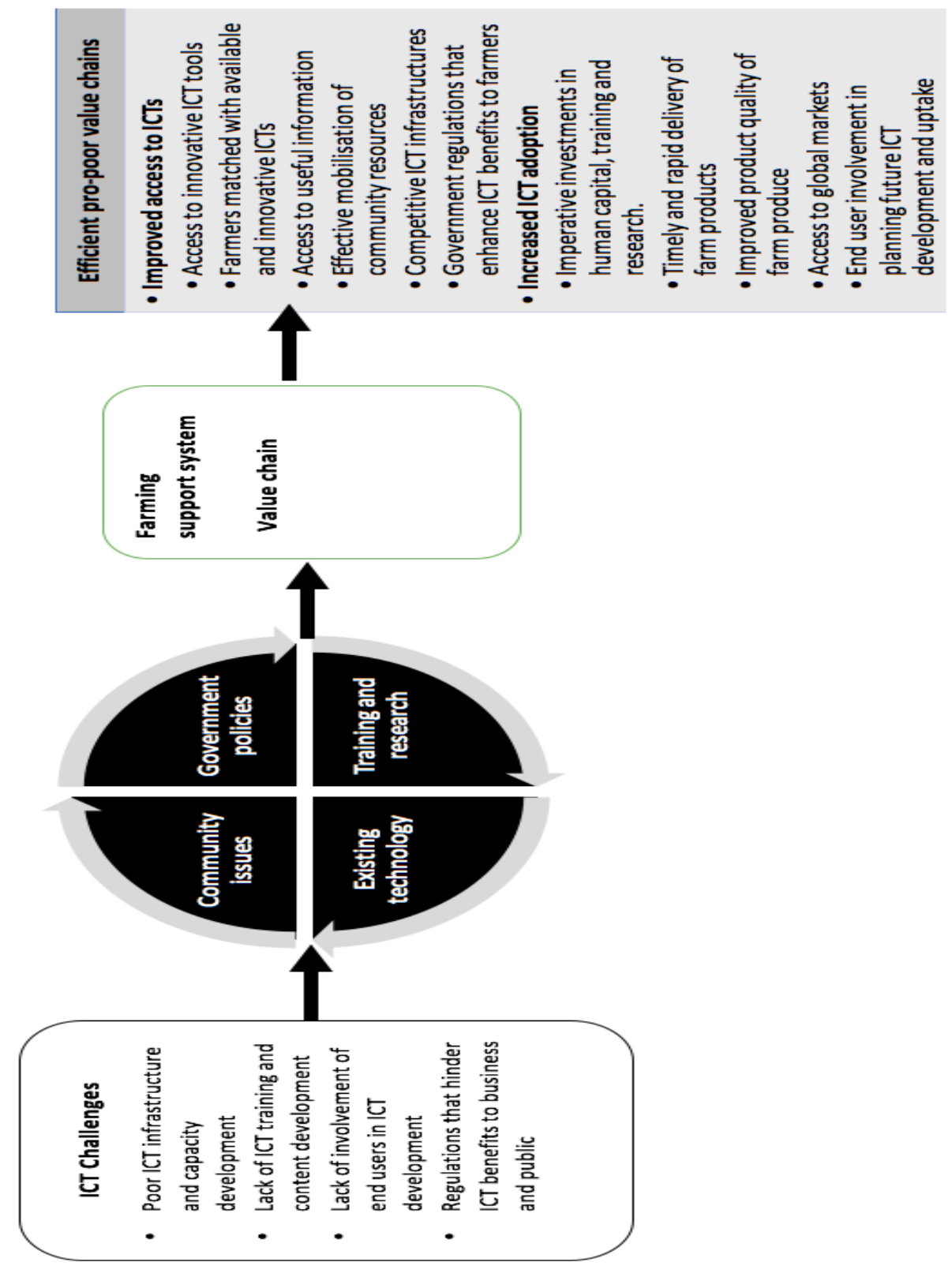

Figure 1: Proposed conceptual model to be used for the research study

An increase in the ICT adoption rate of small-scale farmers in pro-poor value chains requires that the challenges to the uptake of technology innovations in such value chains be addressed for each of the categories outlined in the model. Key factors related to each category are highlighted in Table 2 below. These will be used to identify the ICT-related resources that are required to strengthen the capacity of innovation systems to develop, adopt, and diffuse new technologies effectively for small-scale farmers, and to define strategies that will promote the sustainability and development of small-scale farmers in pro-poor value chains.

Table 2: Core factors in poor adoption of and access to ICTs

\begin{tabular}{|l|l|l|l|}
\hline Challenges & Factor 1 & Factor 2 & Factor 3 \\
\hline Government policies & Government regulations & Funding & Market interactions \\
\hline Existing ICT tools & Complex ICTs & Expensive ICTs & Inaccessible ICTs \\
\hline Research and training & $\begin{array}{l}\text { Effective } \\
\text { programmes }\end{array}$ & Simple ICT tools & Lack of research \\
\hline Community issues & Basic needs & Economic conditions & Human capability \\
\hline
\end{tabular}


Sustainable solutions must consider the local constraints of the smallholder farmer environment, such as lack of infrastructure and data connectivity, and low skills, among others. It is important that ICT solutions effectively connect and integrate input from all stakeholders in order to improve agricultural input supply [31]. For example, a connected crop solution for smallholder farmers could improve the productivity of farmers and increase sales.

\section{RESULTS: EXPERT OPINION SURVEY}

Descriptive and inferential analyses of the results of the expert opinion survey are described here.

\subsection{Sample description}

The sample was dominated by industry workers (48 per cent), as shown in Error! Reference source not found. below. Farmers constituted nine per cent of the sample, while 39 per cent of the respondents were researchers in the field of agriculture.

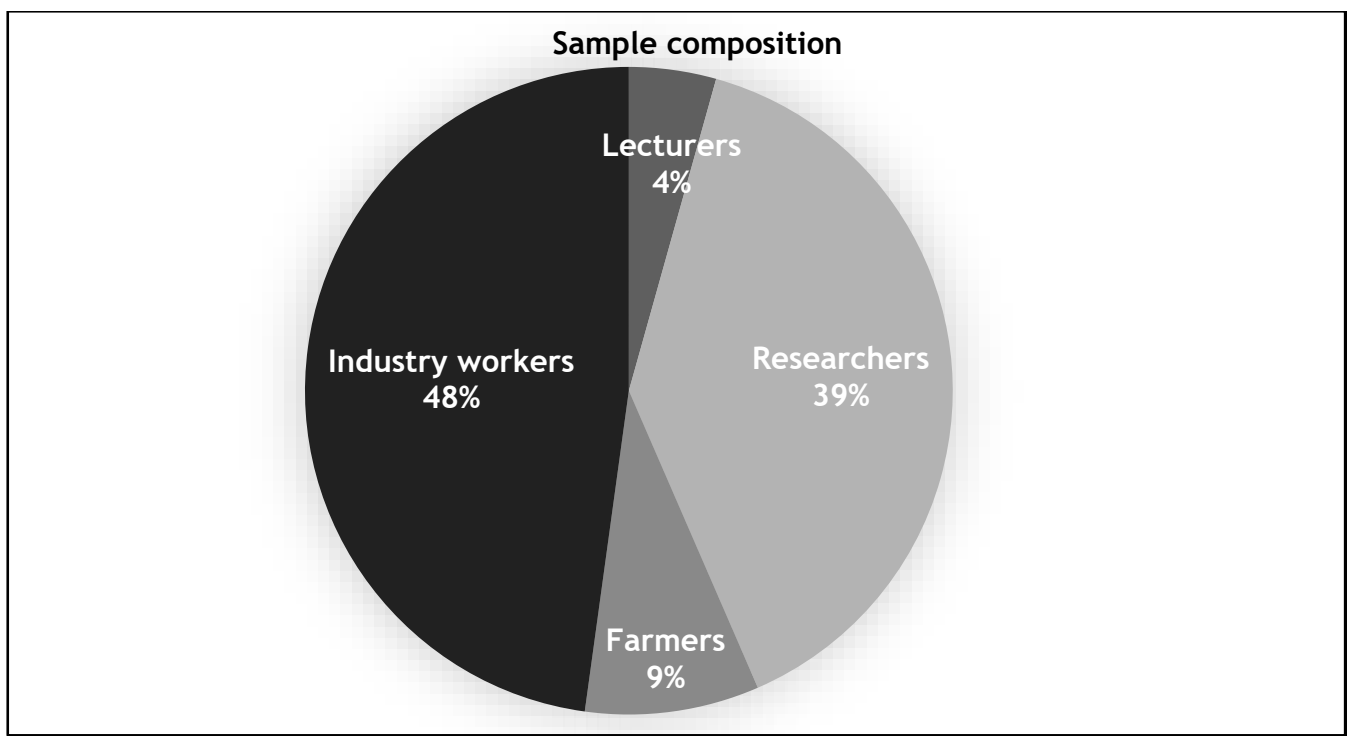

Figure 2: Sample composition used for the research study

\subsection{Challenges}

Figure 3 shows participants' ranking of the key challenges faced by small-scale farmers, and Figure 5 shows the important areas of focus within which to address these challenges.

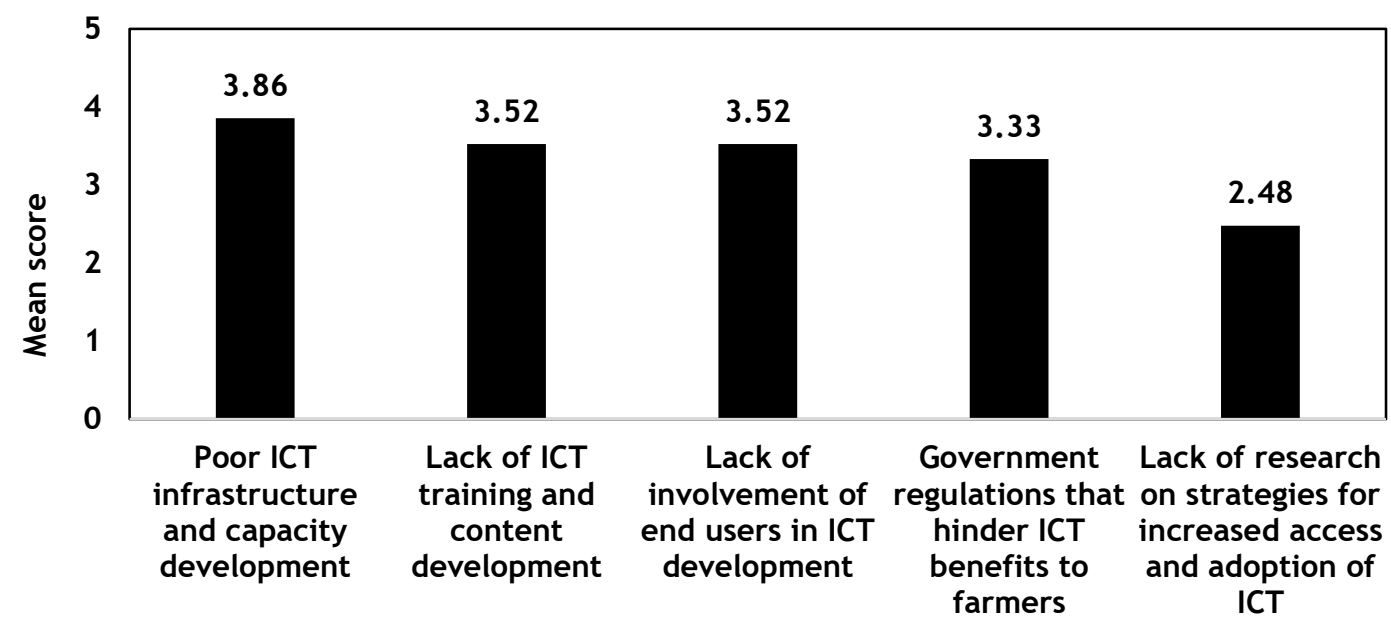

Figure 3: Rating of key challenges faced by farmers 
The respondents ranked all the challenges as important, but indicated that the most pressing challenge faced by small-scale farmers is poor infrastructure and poor capacity development. The mean score for this challenge is 3.86. This indicates a pressing need to develop ICT infrastructure in pro-poor value chains. Respondents also believed that there is a lack of research on strategies for increased access to and adoption of ICT.

The most important focus areas for addressing these challenges, shown in Figure 4, are government policies and training of small-scale farmers on the use of ICTs, with mean scores of 3.95 and 3.81 respectively.

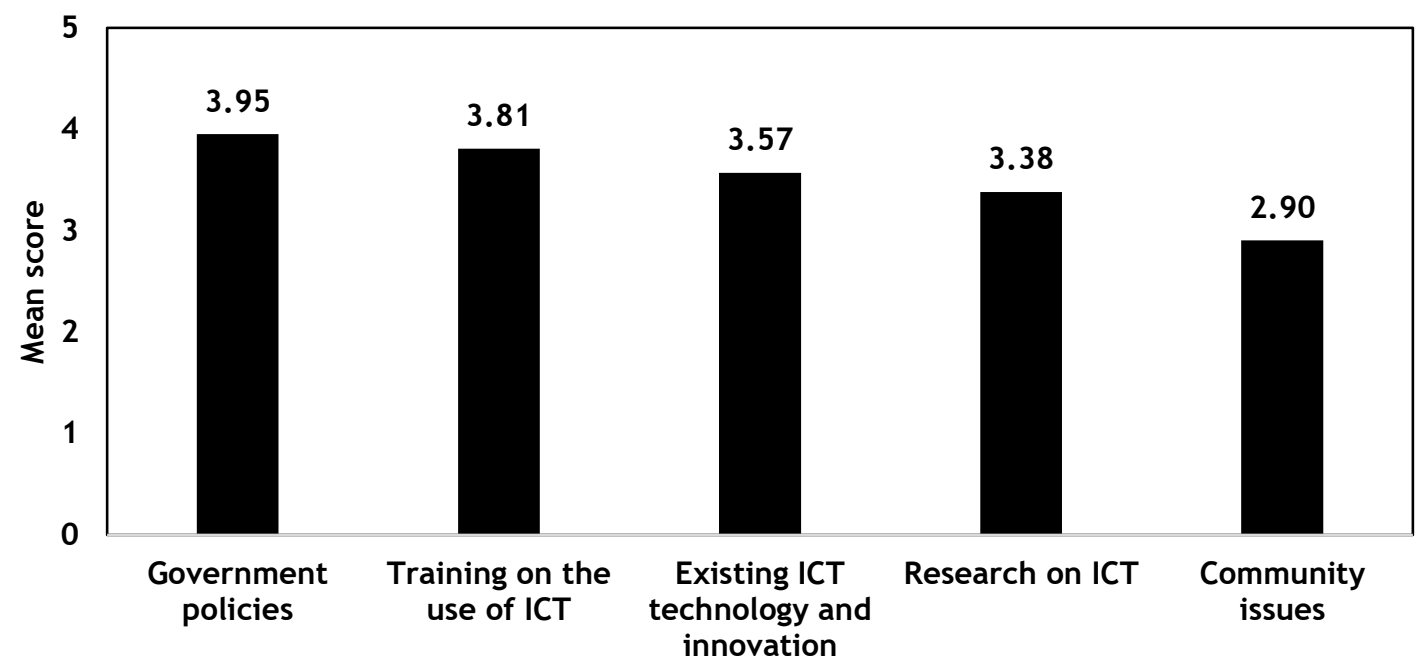

Figure 4: Important areas of focus to address ICT challenges

\subsection{Government strategies}

Figure 5 shows the results of the rankings of the government strategies that are required in order to address the challenges of ICT adoption by small-scale farmers in rural areas. The respondents ranked the development of infrastructure facilities in rural areas as the most important focus area for government, with a mean score of 3.81. The second-highest rated strategy (with a mean score of 3.57 ) is the promotion of ICT adoption partnerships to increase farming funds. Respondents also believed that involving all ICT stakeholders in the establishment of all ICT R\&D priorities was important.

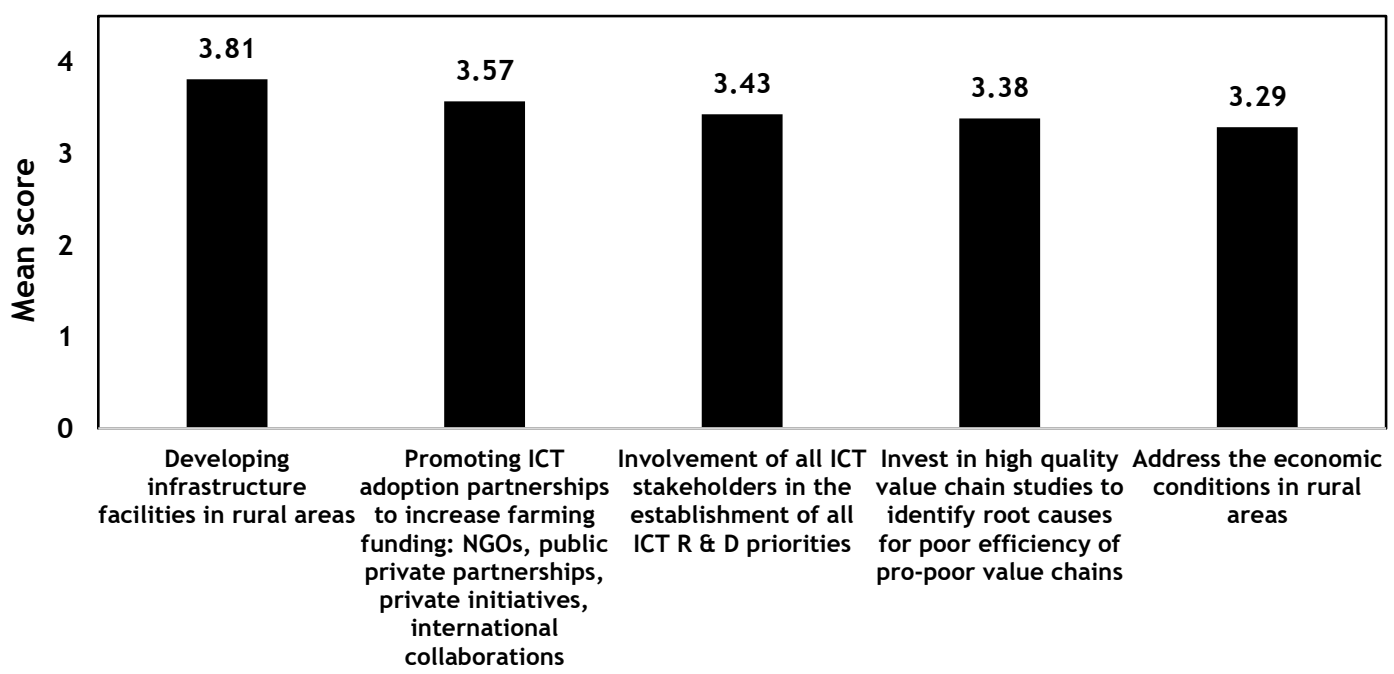

Figure 5: Government strategies to increase ICT access for small-scale farmers 


\subsection{Training}

Increasing literacy and skills for ICT use by implementing ICT studies in primary and high schools received the highest mean score (3.90), as shown in Figure 6. The second-highest ranked strategy (with a mean score of 3.81) is the need to provide free adequate ICT training to small-scale farmers. The third-highest ranked strategy is the sharing of best practices and technical knowledge with other farmers, as well as the development of platforms where farmers can easily access knowledge. These received a mean score of 3.76 .

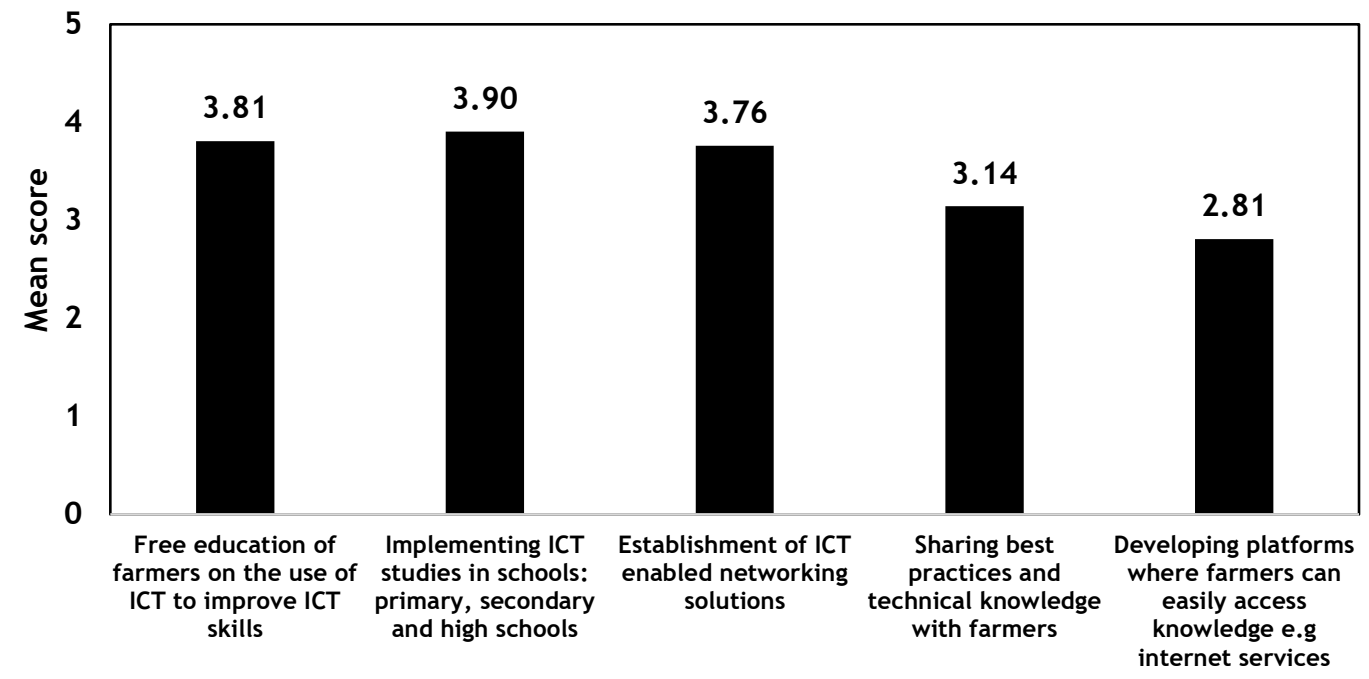

Figure 6: Strategies for ICT training

\subsection{Existing technology}

The majority of participants ranked the price of ICT farming technologies as the focus area with the highest priority, with a mean score of 3.86. The second-highest ranked shortcoming was the ineffective existing ICT technology (overall mean score of 3.71). A mean score of 3.43 was given to the complexity of existing ICTs, as shown in Figure 7.

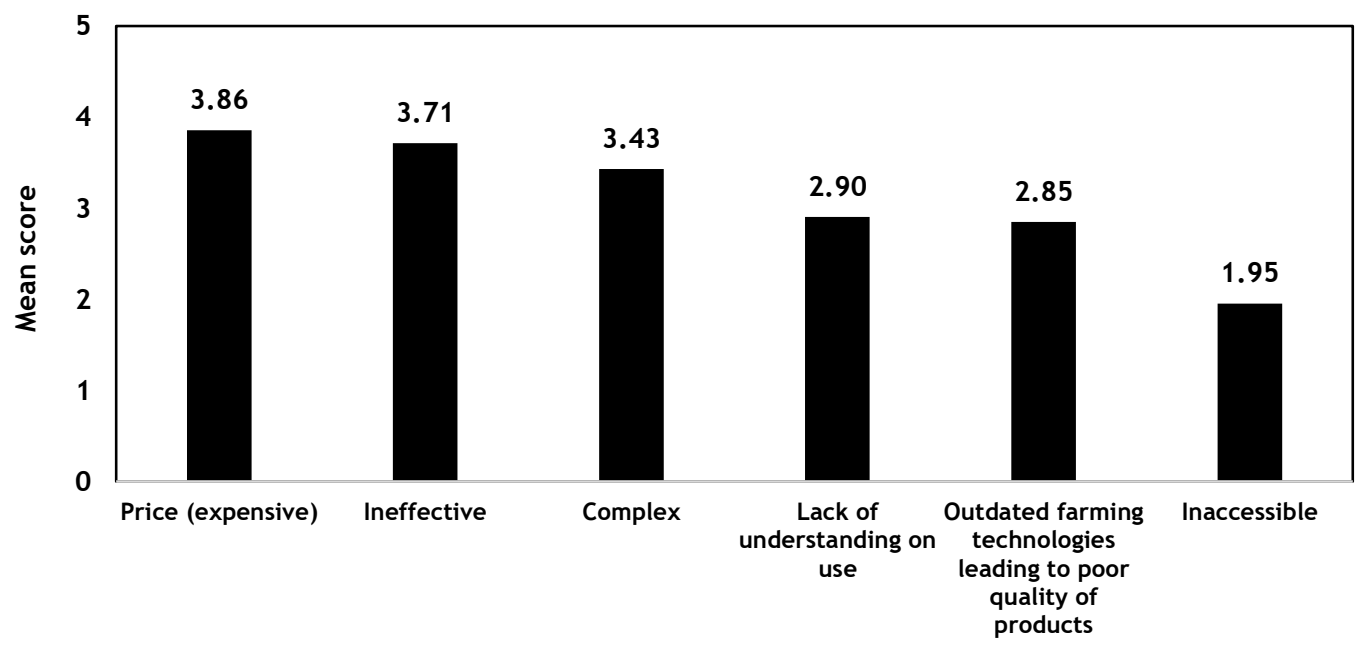

Figure 7: Limitations of existing ICT technology

\subsection{Community issues}

The inconsistent provision, or lack, of basic needs was ranked as the highest priority, with a mean score of 3.70. Respondents believed that this is the most important community issue that must be addressed to increase the adoption and uptake of ICTs by small-scale farmers in pro-poor value 
chains. The focus area with the second-highest ranked priority is the lack of access to available markets, as shown in Figure 8.

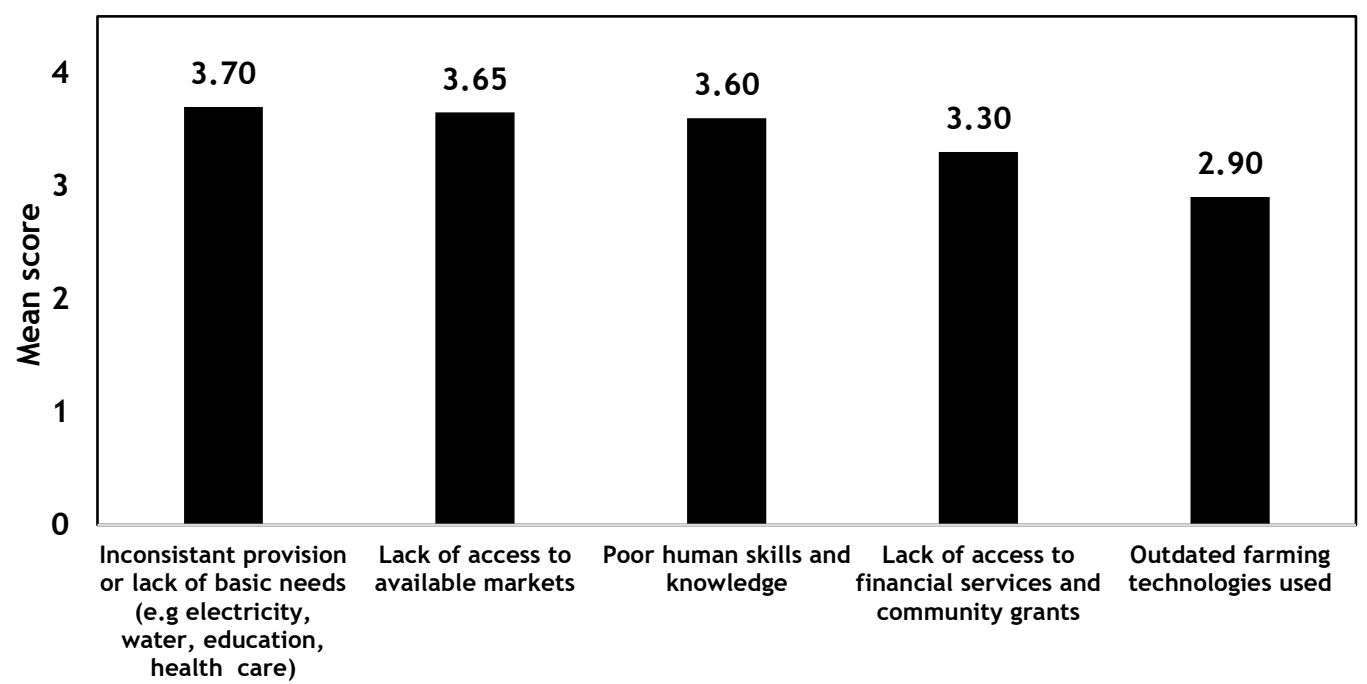

Figure 8: Community issues that must be addressed to increase ICT adoption

\subsection{Mechanisms to increase adoption and utilisation}

The most important support mechanism for ICT adoption is research on ICT access and adoption, with a mean score of 3.29 , as shown in Figure 9. Participants also believed that addressing basic community needs in pro-poor value chains was the second most important support mechanism (with an overall mean score of 3.19). The results showed that the need to establish government policies that support and meet the needs of small-scale farmers in pro-poor value chains was the third most important support mechanism to explore.

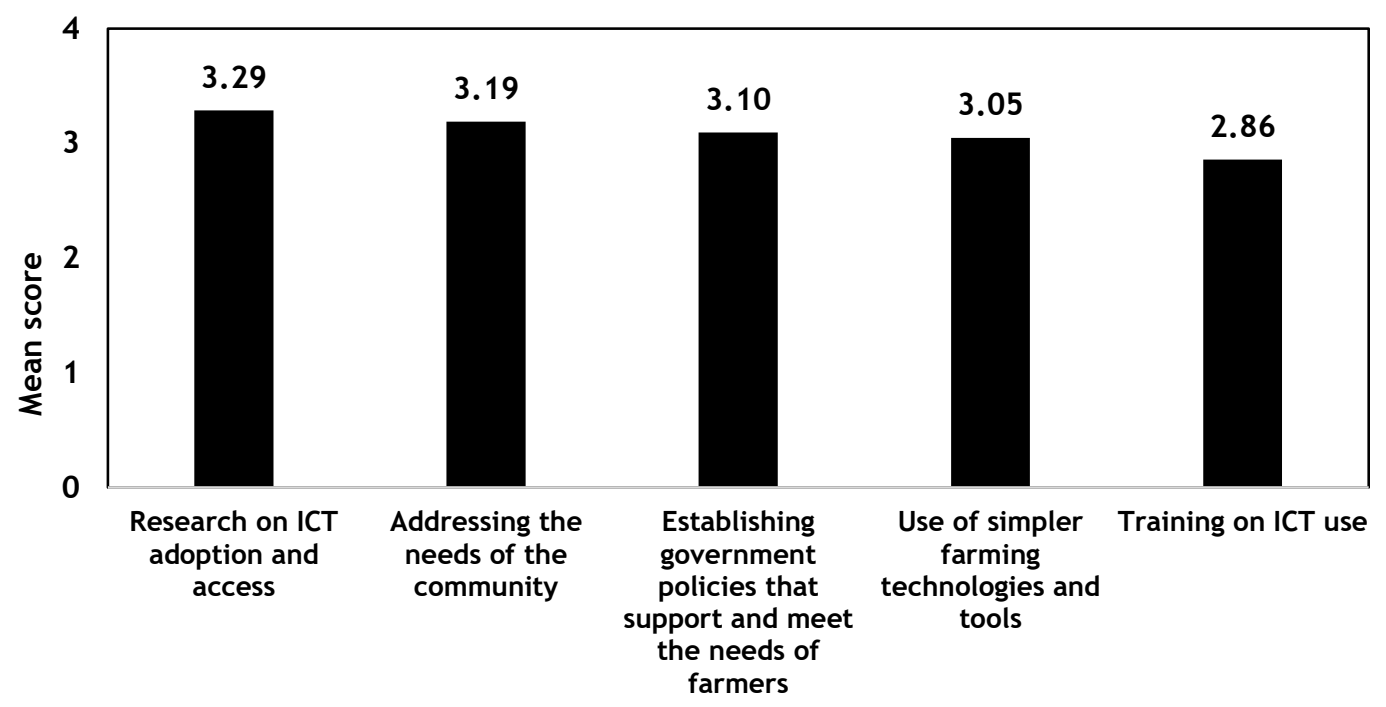

Figure 9: Support mechanisms required to increase ICT adoption

Media platforms were deemed to be the most effective ICT platforms to improve farming methods in rural areas, as shown in Figure 10. This received the highest mean rank of 3.57 out of 5. The second-highest ranked ICT platform was mobile technology, followed by farmers' schools, with mean scores of 3.48 and 3.38 respectively. The lowest rating was given to the establishment of value chains. 


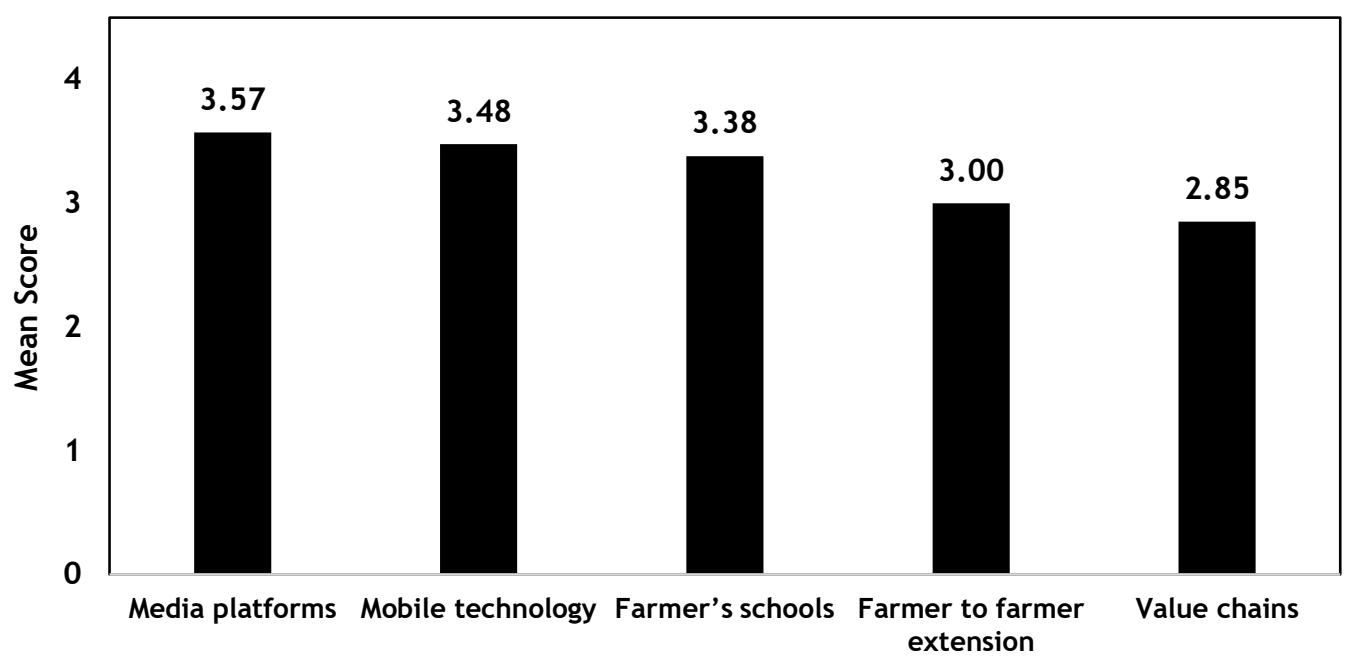

Figure 10: ICT platforms that can be used to increase ICT adoption

Participants also gave their own opinions on how farmers can properly use available ICTs to support and develop small-scale farmers in pro-poor areas.

All respondents echoed the importance of ICTs for the development of rural small-scale farming. One respondent said: "ICT farming tools can assist farmers to make informed choices regarding their crops, e.g., what to grow when and where to sell their products. But to do this, there is a need to encourage growth of locally appropriate, affordable, and sustainable ICT solutions for rural farmers". ICTs will assist farmers "to access production tips, weather updates, connect with input suppliers and aggregators, insurance providers, money transfer, communicate virtually with extension officers and other farmers within and beyond borders".

"The first important area of focus is to increase the capacity and capability of human capital. Therefore, it is important to assist small-scale farmers to increase their ICT knowledge and skills. "The first thing to be done to them is to first train them and give them basic education or adult education, as some of them are not educated. You cannot train them to use ICTs if they do not first have this basic knowledge. For example, how to write and read." "Farmers need to be capacitated on what they can or cannot do with the already available ICT technologies." "Farmers need constant training on the use of available ICTs. They also need to form small groups to assist one another."

The government can assist with developing training programmes for small-scale farmers in the rural areas. "By focusing on training, the farmers first use the existing ICT infrastructures before even proceeding with further complex ICTs. Also, making it easier for them to access the existing technology." Knowledge and understanding of existing ICTs will ensure that farmers are able to use available ICTs effectively to increase their production. Once farmers have been trained to use the existing ICT tools, they will be able to use new and complex ICTs.

Respondents considered it as important that the benefits of ICTs are communicated well to farmers. "Furthermore, it's important the basic needs of these farmers and their communities be met, if not, this may pose a big distraction to the farmers."

Respondents mentioned the importance developing ICTs that are easy to use by the average smallscale farmer. "Farmers will be able to use ICTs that are accessible, easy to use, well supported (not 'white elephants' that become useless because tech support is lacking), and that address a real need. Simple platforms that are already in use, and that can provide a useful means of information sharing, can work (e.g., social media platforms - see Oxfam's PROTIC initiative in Bangladesh)." "Available ICTs should be tailored to meet the needs of small-scale farmers." "Farmers must have access to simple ICT platforms and providers must make use of available ICT tools e.g. phones, which most small-scale farmers have access to." 
Generating funding to purchase existing ICTs is also deemed as important. "There must be financial support from the public and private sector to fund the acquiring of the technology." It is important to "reduce the supply chain and implement the already available ICT equipment effectively. Government should increase funding and provide training for free too." "ICT should be readily accessible to farmers, the cost of adopting ICT should not exceed the cost of returns from the investment."

It is important to "start with the basics. As it stands some farmers do not even have emails because they do not have the right tools, e.g., a computer, laptop, or internet connection. Internet service providers should also consider expanding their network coverage to reach remote areas, and probably have subsidised prices for their areas." "Stakeholders must understand constraints to ICT adoption and access, introduce appropriate ICT to address most pressing needs, train farmers in the use of ICT, provide ongoing support and maintenance, and ensure ongoing functioning of the system."

Respondents alluded to the need to meet the needs of farmers, such as electricity and water. Since rural areas are remote and underdeveloped, it was highlighted that government must address the economic condition of rural areas. Assisting and supporting entrepreneurship in the rural areas, through the use of ICTs, will help to minimise poverty.

Partnerships with stakeholders are important for generating funding to purchase the current ICTs for use by small-scale farmers in rural areas. "Through vigorous engagement with stakeholders like extension officers, through the use of organizations like National Agricultural Unions, and through assistance from donors to teach local youth strategies that can interest the farmers." "Capacity building on the use of ICT services, formation, organisation, and management of small-scale farmers' groups should be part and parcel of the development, design, and implementation of ICT intervention packages in rural areas."

Respondents indicated that farmers in rural areas have a role to play in developing their farming activities. Farmers should first take the initiative to improve and develop their farms. They must change their attitudes to ICTs, and work towards adopting new ICTs. Farming extensions are platforms where farmers can learn from each other, share their challenges and best practices, and help each other to adopt ICTs. "The farmers should firstly be exemplary leaders in ICT and prove to adopt ICT innovations. They can share their knowledge and expertise by hosting small-scale farmers on their farms in the form of one-on-one interactions and practical know-hows, thus feeding off one another's strengths and weakness."

\section{DISCUSSION AND RECOMMENDATIONS}

The research results show that respondents face different pressing challenges with ICTs, based on their locations. However, the challenges are common across the different locations. All respondents complained about the poor ICT infrastructure and capacity development in the rural areas. Since farmers are not exposed to current and efficient ICT infrastructure, there is limited capacity to train farmers in the use of ICTs.

The results further point to the need to expose small-scale farmers to current and simple ICT tools that will develop their farming businesses. Stakeholders are required to invest in ICTs in rural areas. The areas of focus that were highlighted from the research results are shown in Table 3.

Table 3: Areas of focus for increasing ICT adoption

\begin{tabular}{|l|l|l|l|}
\hline Challenges & Factor 1 & Factor 2 & Factor $\mathbf{3}$ \\
\hline Government & ICT infrastructure & Partnerships with investors & Community needs \\
\hline Existing ICTs & Simple ICT tools & Human resource capability & Access and cost \\
\hline Research and training & ICT infrastructure and tools & Investment in research & Training programmes \\
\hline
\end{tabular}

Strategies for improving the ICT adoption rates for rural small-scale farmers include involving the community in efforts to adopt new technologies. The ICT adoption process must include understanding and addressing the key requirements for users in terms of end-user skills, their realities, and their motivation. This must then be followed by educating communities in the use of ICT tools to improve their ICT skills. Opportunities exist for government to invest in ICT 
infrastructure and capacity in the rural areas. At the same time, government regulations and policies must enable ICT benefits in rural areas.

The effective use of available ICTs requires knowledgeable human resources. Addressing community issues in the rural areas with ICTs will help to increase ICT adoption rates. Existing ICT technology and innovation can be developed in the rural areas for small-scale farmers to use. Focusing on innovative programmes that improve the existing available ICT tools used by small-scale farmers will also minimise the cost of the diffusion of newly developed ICTs. This will avoid investment in and oversupply of superfluous information and the latest, rather than the most relevant, ICT [32].

Investment in research will enable the development of simpler ICT tools that can increase access to ICTs and trigger learning that leads to adopting more advanced ICTs [33]. Effective training programmes should be identified to expose farmers to efficient research that will help to develop effective pro-poor value chains. Funding for these activities can be obtained by encouraging business to exploit opportunities in rural areas, and through collaboration between government, the IT sector, rural communities, researchers, project managers, and end-users. Instruments can be implemented by government to incentivise and catalyse private and financial sector participation in the development of small-scale farmers.

Figure 12 below summarises the suggested process to follow to increase access to, and the adoption of, ICTs in the rural areas for small-scale farmers.

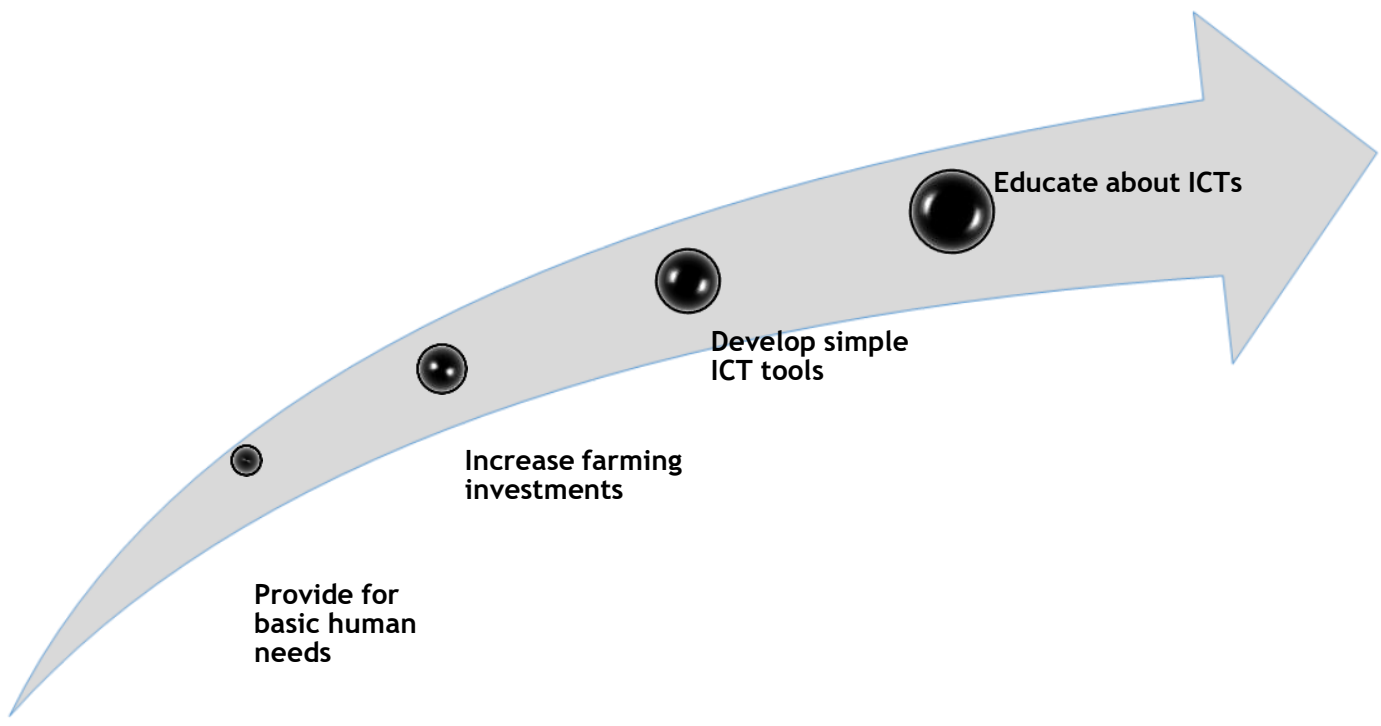

Figure 11: Recommended improvement method for increasing ICT adoption

\section{CONCLUSION}

This research investigated the challenges of adopting and using ICTs as a way to improve the value chains of small-scale farmers in rural areas, and investigated potential strategies to enhance uptake and use. Challenges were identified and categorised, based on a review of the literature, and challenges and strategies for enhancing ICT uptake were ranked through an expert review. Recommendations spanned the entire ICT4D spectrum and context of interventions, from the participatory design of interventions to the development of an enabling policy and regulatory environment.

The research had the following limitations:

- $\quad$ The study was limited to South African small-scale farmers in rural areas; and

- The availability of funds constrained the extent of data collection.

Future research could investigate the evolution of challenges and their resolution over time. The readiness of the smallholder environment to take up interventions could be explored; critical success 
factors in the sustainability of proposed interventions could be examined; and an appropriate implementation strategy could be developed. The research could also be extended to investigate the challenges of and strategies for pro-poor value chains other than in agriculture.

\section{REFERENCES}

[1] Kleine, D. and Unwin, T. 2009. Technological revolution, evolution and new dependencies: What's new about ICT4D?, Third World Quarterly, 30(5), pp. 1045-1067, DOI:10.1080/01436590902959339.

[2] Nederlof, S., Wongtschowski, M. and van der Lee, F. 2011. Putting heads together: Agricultural innovation platforms in practice, Bulletin 396. KIT Publishers, Amsterdam, the Netherlands, p. 192.

[3] Greenberg, S. 2013 Smallholder and agri-food value chains in South Africa: Emerging practices, emerging challenges. Cape Town: University of the Western Cape.

[4] Grobbelaar, S.S. and Meyer, I.A. 2017. The dynamics of regional economic integration: a system dynamics analysis of pathways to the development of value chains in the Southern African Customs Union. South African Journal of Industrial Engineering, 28(1), pp.73-89.

[5] Bage, L. 2008. Supporting smallholders is crucial to food security. [Online] Available at: www.ifad.org/events/op/2008/g8.htm [Accessed 28 March 2017].

[6] Richardson, D. 2006, ICTs: Transforming agricultural extension?. s.l.: The ACP-EU Technical Centre for Agricultural and Rural Cooperation (CTA).

[7] Goldblatt, A. 2010, Agriculture: Facts and trends, South Africa. Cape Town: WWF-SA.

[8] Lisha, A. 2006, Access to ICT in Sub-Saharan Africa: Civil society and governance. Stellenbosch: Stellenbosch University.

[9] Gelb, E., Maru, A., Brodgen, J., Dodsworth, E., Samii, R. and Pesce, V. 2008, Adoption of ICT enabled information systems for agricultural development and rural viability. The Global Forum on Agricultural Research, Atsugi.

[10] Foster, R. 1986. Innovation: The attacker's advantage. New York: New York Summit Books.

[11] Cooke, P. and Memedovic, O. 2003. Strategies for regional innovation systems: Learning, transfer and applications. Cardiff: UNIDO

[12] Stoian, D., Dayden, M. and Muller, M. 2012. Value chain development for rural poverty reduction: A reality check and a warning, Enterprise Development and Microfinance, 23(1), pp. 1755-1986.

[13] Carpentier, C. 2008, Agricultural technology for development: Old Issue, New Context Secretary General's Report to the 64th General Assembly. [Online] Available at

https://sustainabledevelopment.un.org/content/documents/Agrtechdev-v6.pdf [Accessed 29 November 2019].

[14] Firdhous, M., Ghazalli, O. and Hassan, S. 2013. Cloud computing for rural ICT development: Opportunities and challenges, International Conference on Computing Electrical and Electronics Engineering (ICCEEE) (2013), pp. 680-685.

[15] Qwabe, N. 2014, Lending to small-scale farmers in South Africa: A case for best practices in formal institutions. Pretoria: University of Pretoria.

[16] Kambanje, C. 2008. Sustainable food value chain development. s.l.: Food and Agriculture Organization of the United Nations (FAO).

[17] Brooks, S. 2011. Shaping agricultural innovation systems responsive to food insecurity and climate change, Natural Resources Forum, 35, pp. 185-200.

[18] Africa. 2018. Agrilinks.org, [Online] Available at https://agrilinks.org/sites/default/files/resource/files/ICT\%20Applications\%20for\%20Agricultural\%20Inpu t\%20Supply\%20Companies\%20presentation.pdf [Accessed 12 January 2018].

[19] Meera, S., Julius, A. and Rumi, D. 2004. Information and communication technology in agricultural development: A comparative analysis of three projects from India, Agren, 135, pp. 1-20.

[20] NECTEC. 2002. ICT for poverty reduction: Examples of programs/projects in Thailand. Bangkok: National Electronics and Computer Technology Center.

[21] Cuthbert, K. 2014. Sustainable food value chain development, Food and Agriculture Organisation of the United Nations.

[22] Ngowi, E., Maumbe, A. and Majola, D. 2015. Making ICTs work for agro-pastoral livelihood: Using the telecentre as learning tool for agro-pastoralists communities in Tanzania, Journal of Sustainable Development, 8(2), pp. 89-98.

[23] Osunyomi, B. 2013. Exploring the role of information and communication technology in response to HIV/AIDS: Boosting awareness, prevention, treatment and care in South Africa. Pretoria: University of Pretoria.

[24] Kuntagod, N., Paul, S., Kumaresan, S., Ganti, S. and Yala, G. 2015. Last-mile wireless connected crop solution for smallholder farmers. Bangalore: Accenture.

[25] Food and Agriculture Organization (FAO). 2014. Developing sustainable food value chains: Guiding principles. Rome: FAO.

[26] Trade, A. and Guod, D. 2013. A short guide to pro-poor value chain program design. Arlington: Action for Enterprise.

[27] Dorward, A.K.J. 2004. A policy agenda for pro-poor agricultural growth, World Development, 32(1), pp. 73-89.

[28] Department of Agriculture, Forestry and Fisheries (DAFF). 2014. Agricultural policy action plan (APAP). Pretoria: Department of Agriculture, Forestry, and Fisheries. 
[29] Rogerson, C.M. 2005. Ekurhuleni: Towards a local industrial policy for driving pro-poor growth and a people-centred economy. Case Study prepared for the World Bank-Netherlands Partnership Program Evaluating and Disseminating Experiences in Local Economic Development (LED) Investigation of Pro-Poor LED in South Africa, 2005. [Online] Available at:

http: / / siteresources.worldbank.org/INTLED/Resources/339650-1144099718914/ProPoorEkhurleni.pdf [Accessed 29 November 2019].

[30] Maumbe, B.M. and Okello, J.J. 2013. Technology, sustainability, and rural development in Africa. Hershey: IGI Global.

[31] Maumbe, B. 2012. Emerging ICT applications in agribusiness value chains: Market linkages, food security and research directions. New York: Cornell University.

[32] McCormick, D. \& Onjala, J. 2007. Methodology for value chain analysis in ICT industry frameworks for the study of Africa. Nairobi: African Economic Research Consortium.

[33] Lowitt, S. 2008. Linking small and marginalised producers to external markets: New ideas for demandside measures using value chain analysis. [Online] Available at: http://www.tips.org.za [Accessed 1 October 2017]. 